\title{
THE SOCIO-ECONOMIC HISTORY OF LITHUANIA FROM THE 16TH 1 TO THE 19TH CENTURY (UNTIL 1861) FROM THE PERSPECTIVE OF ECONOMIC DEVELOPMENT CONCEPTS
}

\section{Darius Žiemelis}

Lithuanian Institute of History, Vilnius, E-mail: dariusziemelis@inbox.lt

\section{Acknowledgments}

The article was prepared during a Postdoctoral Fellowship, funded by the European Union Structural Funds Programme for the Development of Human Resources for Scholars and other students in research and scientific work incentives (VP1-3.1-WE01) Implemented the project 'Postdoctoral (post doc) Fellowship Implementation in Lithuania'. Material for the theoretical part of the article was collected and analyzed during an internship at the Free University of Berlin (Freie Universität Berlin) on 4 February - 4 March 2013.

\begin{abstract}
:
The article is devoted to the presentation of the economic conceptions of the most influential non-Marxist (Karl Bücher, Max Weber) and neo-Marxists (Witold Kula, Immanuel Wallerstein) disclosing their analytical value in the investigations of the typologization of Lithuania's social economic history in the 16th-19th centuries (up to 1861). It is established that K. Bücher's and M. Weber's conceptions of economic development are best suited to analyze the qualitative changes in the organization of the economic life of the most developed countries in Western Europe (primarily England) rather than the socio-economic reality of the less developed countries. For the research of the latter better suited are the Marxist (W. Kula's model of the feudal economy) and the neo-Marxist (I. Wallerstein's capitalist world-system conception) concepts analyzing the economic development of less developed countries. The typological diagnosis of Lithuania's social economic history in the 16th-19th centuries (up to 1861) is presented.
\end{abstract}




\section{Rezumat:}

Acest articol este dedicat prezentării concepțiilor economice ale celor mai influenți nemarxiști (Karl Bücher, Max Weber) și neo-marxiști (Witold Kula, Immanuel Wallerstein), dezvăluind valoarea lor analitică $\hat{\imath}$ ceea ce privește investigarea tipologizării istoriei socio-economice a Lituaniei din secolul al XVI-lea până în secolul al XIX-lea (până la 1861). Este acceptat faptul că conceptiile lui K. Bücher și M. Weber de dezvoltare economică sunt cele mai potrivite pentru a analiza schimbările calitative in ceea ce privește organizarea vieții economice din țările cele mai dezvoltate din Europa de Vest (în principal - Anglia), mai degrabă decât realitatea socio-economică din țările mai puțin dezvoltate. Pentru cercetarea acestora din urmă mai potrivite sunt conceptele marxiste (modelul lui W. Kula asupra economiei feudale) și neo-marxiste (concepția sistemului mondial capitalist a lui I. Wallerstein) care analizează dezvoltarea economică a țărilor mai puțin dezvoltate. Este realizată diagnosticarea tipologică a istoriei socio-economice a Lituania din secolul al XVI-lea până în secolul al XIX-lea (până la 1861).

Keywords: 16th-19th c. Lithuania's social economic history; non-Marxist and neo-Marxist conceptions of the economy

\section{Introduction}

During the 23 years of the independence of Lithuania the development of Lithuania's economy in 1557-1861 in the context of Europe was not especially or systematically researched, there are only a few episodic discussions in articles or reports at scholarly conferences. ${ }^{1}$ This period in

\footnotetext{
${ }^{1}$ In the agenda of Lithuania's historians one can notice the declining attention to research on Lithuania's social economic and agrarian history (abandoning the methodological approaches of Marxism), which were important in the Soviet period. Noteworthy exceptions in this context are the studies of A. Tyla, S. Pamerneckis, G. Vaskela and Z. Norkus. See Antanas Tyla, Lietuvos Didžiosios Kunigaikštystès iždas: XVI amžiaus antroji puse XVII amžiaus vidurys (Vilnius: Nacionalinis muziejus Lietuvos Didžiosios Kunigaikštystès valdovų rūmai, 2012); Stanislovas Pamerneckis, Agrariniu santykiu raida ir dinamika Lietuvoje: XVIII a. pabaiga - XIX a. pirmoji puse (Statistine analizé) (Vilnius: VU, 2004); Gediminas Vaskela, Lietuva 1939-1940 metais: Kursas ị valstybès reguliuojamą ekonomika (Vilnius: LII, 2002); Vaskela, Žemés reforma Lietuvoje 1919-1940 m.: Analizuojant Rytu ir Vidurio Europos agrarinés raidos XX a. III-IV dešimtmečiais tendencijas (Vilnius: LII, 1998); Vaskela, 'The Course towards StateRegulated Economy in Lithuania in 1939-1940', Lithuanian Historical Studies 2 (1997): 151-174; Vaskela, 'The Land Reform of 1919-1940: Lithuania and the Countries of Eastern and Central Europe', Lithuanian Historical Studies 1 (1996): 116-132; Vaskela, Lietuvos kaimo gyventojai 1920 1940 m. (socialinis ir ekonominis aspektas) (Vilnius: Academia, 1992); Zenonas Norkus, 'Agrariniu reformu Pirmojoje ir Antrojoje Lietuvos respublikose lyginamoji istorinè sociologinè analizè', Sociologija. Mintis ir veiksmas 1 (30), (2012): 5-52; Norkus, 'Kapitalizmo raidos Lietuvoje bruožai ir etapai (iki 1940 m.) postmarksistiniu požiūriu', Lietuvos istorijos studijos 29 (2012): 9-36.
} 
modern Lithuanian historiography still influenced by Marxist ideas is regarded as an era in Lithuania of the dominance of feudal serfdom relations that resulted socio-economic backwardness. The backwardness is explained as a naturally understood matter of course - we are "backward" because we did everything later than in Western Europe. But there was a time when Western Europe was more backward than Egypt or Greece, and North West Europe was more "backward" than Italy. The concept of the neo-Marxist capitalist world system (CWS) by the creator of comparative historical sociology $^{2}$ I. Wallerstein, which emphasizes the importance of external causes on the development of a country, the backwardness (as "chronic", determined by internal reasons) of Central Eastern Europe creates problems for the thesis, offers to look at the history of these states from a global perspective, therefore becomes a significant alternative approach to traditional historiography. ${ }^{3}$ However, this theory - it is just one of the many explanations of the "backwardness" of Lithuania (and thus also of the whole region of Central Eastern Europe). This article will focus on the variety of the most influential non-Marxist and neo-Marxist economic concepts in comparative economic sociology and political economy, disclosing not only their mutual "discussion", but also the analytical value, investigating the socio-economic reality of Lithuania in the 16th-19th c. (up to 1861). We think

\footnotetext{
2 This is a subdiscipline entrenched for five decades in the science of Western history, the foundations of which the fundamental works of R. Bendix, Ch. Tilly, I. Wallerstein and T. Skocpol laid the foundations. See Norkus, Kokia demokratija, koks kapitalizmas? Pokomunistine transformacija Lietuvoje lyginamosios istorinès sociologijos požiūriu (Vilnius: VU, 2008), 79-94; John R. Hall, 'Where History and Sociology Meet: Forms of Discourse and Sociohistorical Inquiry', Sociological Theory, 10, 2 (1992): 164-193. In Lithuania historical studies based on the approach of comparative historical sociology remain an exception up to now. Of them worthy of attention are the works of Zenonas Norkus ('Imperium litewskie w międzyjednostkowych społecznościach i systemach politycznych: studium przypadku', Politeja 2 (2011): 129-154; Nepasiskelbusioji imperija: Lietuvos Didžioji Kunigaikštija lyginamosios istorinès imperiju sociologijos požiūriu (Vilnius: Aidai, 2009); 'The Grand Duchy of Lithuania in the Retrospective of Comparative Historical Sociology of Empires', World Political Science Review 3, 4 (2007): 141.), Saulius Pivoras (Lietuviu ir latviu pilietines savimonés raida: XVIII a. pabaiga - XIX a. pirmoji pusè (lyginamasis aspektas) (Vilnius: VDU, 2000), Kastytis Antanaitis (Sovietiné Lietuvos, Latvijos ir Estijos nomenklatūra (1953-1990 m.: Désningumai ir ypatumai, Daktaro disertacija (Vytauto Didžiojo Universitetas, 2001) and Nerijus Babinskas, "Economic Challenges of the Early Modern Ages and Different Responses of European Margins: Comparative Considertions on the Basis of Historiography (The Cases of Polish-Lithuanian Commonwealth and Moldavian Principality)", Revista Română de Studii Baltice și Nordice / The Romanian Journal for Baltic and Nordic Studies 4, 2 (2012): 51-62.

${ }^{3}$ A decisive role is assigned to the involvement of Central Eastern European countries into the status of the CWS periphery. The CWS concept is presented in part I. 2 of this article.
} 
that the application of the provided typologizing rather than an individualizing approach of these concepts makes it possible to reveal adequately and evaluate Lithuania's economic development in the 16th-19th c. in the context of Europe. It should be noted that in the current historiography of Lithuania there are studies that provide the typological characteristics of Lithuania's economic development. Alfredas Bumblauskas offers to call Lithuania's economy in the 17th-18th c. from the viewpoint of integral civilization history with the term of a baroque economy. ${ }^{4}$ The methodological approaches of this article that allow one to investigate the history of Lithuania's economy in the 16th-19th c. (up to 1861), using the ideas of the classics of economic sociology and political economy on the analysis of the economic development, is provided by the latest research of one of the representatives of Lithuanian historical sociology Zenonas Norkus - "The Features and Stages of the Capitalist Development of Lithuania (before 1940) from the Post-Marxist Viewpoint" 5 . In it, without bypassing the period of our interest, the greatest attention is focused on the economic realities of the 1918-1940 inter-war Lithuania. So the aim of this article is to present the most influential non-Marxist and neo-Marxist economic concepts disclosing their analytical value in the investigations of the typologization of Lithuania's social and economic history in the 16th-19th c. (up to 1861).

The article consists of two parts and conclusions. The first part presents the ideas of the non-Marxist (K. Bücher, M. Weber), and neoMarxist (W. Kula, I. Wallerstein) analysis of the economy. The second part, relying on the basis of presented non-Marxist and neo-Marxist conceptions of the analysis of the economy, an analysis of Lithuania's social economic history in the 16th-19th c. (up to 1861) is carried out. The article ends with conclusions.

\footnotetext{
4 See Alfredas Bumblauskas, Senosios Lietuvos istorija 1009-1795 (Vilnius: R. Paknio leidykla, 2005), 324; Bumblauskas, 'Lietuvos istorijos periodizacijos modeliai socialinès istorijos požiūriu', Lietuvos istorijos studijos 17 (2006): 22-25.

5 Norkus, 'Kapitalizmo raidos Lietuvoje bruožai ir etapai (iki 1940 m.) postmarksistiniu požiūriu', Lietuvos istorijos studijos, 29 (2012): 9-36. 


\section{The Most Influential Concepts of Economic Development}

\section{Ideas of the Non-Marxist Analysis of the Development of the}

\section{Economy}

In the second half of the 19th c. - the beginning of the 20th c. one of the most important areas in the agenda of the representatives of the "historical school" in the national economy ${ }^{6}$ of Germany were the studies of long-term trends in economic life the products of which were different "models of the steps" of economic evolution.7 Two researchers of this school are particularly important for the issues of our research. They are the economic historian of the younger generation Karl Bücher (1847-1930), who provided an evolutionary scheme of economic development, and the economic historian and historical sociologist of the youngest generation Max Weber (1864-1920).8 The latter critically develops the three-stage evolutionary economic theory of K. Bücher and provides an explanation of the emergence of modern capitalist economic life in Western Europe in recent times, and its distinctive features.

K. Bücher (1893) in his famous work "The Origin of the National Economy"9 provides an evolutionary typology of economic development, "domestic economy" (i.e. subsistence economy, producing for the use of its members), "town economy" (that is a local exchange economy, which is characterized by production for buyers, but still with a direct relation between producers and consumers) and "national" or "people's economy" (this is an interlocal economy of exchanges, which is characterized by mass

\footnotetext{
${ }^{6}$ This is the name at that time of the German science of economics.

7 See Zenonas Norkus, Max Weber und Rational Choice (Marburg: Metropolis Verlag, 2001), 344-345; Peter Ghosh, 'From the 'Spirit of Capital' to the "Spirit" of Capitalism: The Transition in German Economic thought between Lujo Brentano and Max Weber', History of European Ideas 35, 1 (2009): 62-92.

8 In this historical school three generations of researchers are distinguished: 1) older (Bruno Hilderbrand, Karl Kniesa, Wilhelm Roscher); 2) younger (Lujo Brentano, Karl Bücher, Georg F. Knapp, Gustav Schmoller); 3) youngest (Werner Sombart, Arthur Spiethoff, Max Weber and his younger brother Alfred Weber). See Norkus, Max Weber und Rational Choice, 57. Also see Heino Heinrich Nau, 'Gustav Schmoller's Historico-Ethical Political Economy: Ethics, Politics and Economics in the Younger German Historical School, 1860-1917', The European Journal of the History of Economic Thought 7, 4 (2000): 507-531; Patrick Mardellat, 'Max Weber's Critical Response to Theoretical Economics', The European Journal of the History of Economic Thought 16, 4 (2009): 599-624.

9 Karl Bücher, Die Entstehung der Volkswirtschaft. Sechs Vorträge (Tübingen: Verlag der H. Laupp'schen Buchhandlung, 1893). Russian translation: Karl Bücher, Vozniknovenie narodnogo hoziaistva: publichnyje lekcii $i$ ocherki / perevod pod redakciei i s predisloviem I. M. Kulishera. Vypusk pervyi (Sankt Peterburg, 1907).
} 
production for an anonymous market). ${ }^{10} \mathrm{~K}$. Bücher considered the domestic economy characteristic for Antiquity, the town economy - for the Middle Ages (from the 12th c.) national economy - for latest times. The distinguished steps were different in the spread of the division of labor, which is expressed in the prolongation of "the path that the product goes from producers to consumers"11. The product manufactured in the domestic economy is consumed on the spot (i.e., it is based on a production and consumption association), in the town economy he travels to the consumer economy and in the national economy he goes through many economies. This means that in the national economy the production and consumption associations are separated from each other. ${ }^{12}$

The development of the division of labor - is an essential, but not the only distinguishing feature of K. Bücher's three economy types. With it are associated other features of the stages of economic development: the relation with a foreign labor force, crafts, money, capital and trade. In the domestic economy when the need for a foreign labor force appears, the relationship between the owner of the farm and persons unrelated by blood becomes forced (slaves, serfs), in the town economy - service, in the national - shortterm contractual. In the domestic economy initially there is no money. Only later they become the means of direct use or of the collection of values. In the town economy money is the medium of exchange, in the national economy - a tool of turnover and getting profit. In the domestic economy there is no capital, only consumer goods. In the town economy only the means of production are considered to be industrial capital, but not raw materials. ${ }^{13}$ In the national economy everything becomes capital. Because of this the economy is identified as capitalist. ${ }^{14}$ In the domestic economy there is no profession of a craft, in the town economy professional craftsmen appear, but there no entrepreneurs. In the national economy manufaktura and factories dominated, which implies the existence of entrepreneurs working

\footnotetext{
10 See Bücher, Vozniknovenie narodnogo hoziaistva, 82. It should be noted that K. Bücher's contemporaries already added a fourth typology - the evolutionary type of the "world economy", which later in the works of the famous French historian Fernand Braudel turned into the concept of the "economic world", see Zenonas Norkus, "Andropovo klausimu (II). Kaip Maxas Weberis atsakytų i Jurijaus Andropovo klausimą', Sociologija. Mintis ir veiksmas 1 (21) (2008), 9.

11 Bücher, Vozniknovenie narodnogo hoziaistva, 82.

12 See Bücher, Vozniknovenie narodnogo hoziaistva, 128-129.

13 See Bücher, Vozniknovenie narodnogo hoziaistva, 129.

14 See Bücher, Vozniknovenie narodnogo hoziaistva, 129-130.

62
} 
on a commercial basis and great capital. Finally, trade in the domestic economy can be described as nomadic, in the town economy it occurs in the market and in the national economy it is of a permanent nature. In the first two types trade is just a method of plugging the holes in autonomous production, in the third - the essential link between the producer and the consumer. ${ }^{15}$

The greatest authority on ancient history at that time Ernst Meyer criticized K. Bücher's evolutionary typology of economic development at that time. ${ }^{16} \mathrm{He}$ tried to prove that the features of national economy, which, in his opinion, is identified as "capitalism" was already characteristic in antiquity (especially in the times of Hellenistic and Roman reign). E. Meyer claimed that the history of antiquity from the view point of medieval and modern history is not a step of more than one process of consistent historical development, but an independent cycle, the main features of the dissemination of which the history of post antique Europe repeats. As shown by one of the most famous interpreters of $\mathrm{M}$. Weber and his legacy researcher $Z$. Norkus, the result of the explanation of the emergence of M. Weber's capitalist national economy from the medieval town economy was drawn into this discussion (i.e. is capitalism a modern phenomenon?). ${ }^{17} \mathrm{M}$. Weber as a historical sociologist and economic historian raised the question why was it that in the West (and not, for example, in China) for the first time in the world there appeared rational / modern capitalism (as an economic macro-system and a type of activity), and why did it develop in the 17th-19th c. rather than, for example, in ancient Rome in the 1st-2nd c. It should be noted that M. Weber's view of the economic history of the Western world, which is presented in the most detailed in "Features of universal economic and social history"18 is considered to be not only a (critical) addition to K. Bücher's evolutionary typology of economic development. ${ }^{19}$ His theory

\footnotetext{
15 See Bücher, Vozniknovenie narodnogo hoziaistva, 130-131.

16 See Norkus, Max Weber und Rational Choice, 344-348.

17 See Norkus, Max Weber und Rational Choice, 344-348.

18 This, relying on the listeners compendiums of lectures by M. Weber in the winter semester of 1919-1920 at the University of Munich, 1923 published work of "Economy history" (Max Weber, Wirtshaftsgeschichte: Abriss der universalen Sozial- und Wirtshafts-Geschichte (München: Duncker und Humblot, 1923)). English translation: Max Weber, General Economic History (New York: Collier Books, 1961). More detail and continuation of this view see Max Weber, The Protestant Ethic and the Spirit of Capitalism (New York: Scribner, 1958).

${ }_{19} \mathrm{M}$. Weber uses K. Bücher "steps" only as "ideal types", see Norkus, Max Weber und Rational Choice, 346.
} 
was also an alternative to the "dialectical" conception of Karl Marx, which is very similar to the typologies of the economy of the "historical school". ${ }^{20}$ In the main work of K. Marx "Capital" three main types of evolutionary economy are distinguished: 1) farms the goal of production of which is the "consumption value" 2) farms the goal of production of which is "exchangeable value" 3) farms the goal of production of which is "added value". 21

Unlike K. Bücher, M. Weber gave not one, but two alternative directions, for which the transformation of the primitive subsistence "domestic economy" may occur. One of them leads to K. Bucher's "town economy". Characteristic for it were the local markets, in which for the exchanges of daily use products the buyers meet directly with their manufacturers. From the town economy, under a certain constellation of historical conditions, did capitalism emerge as an economic system of the national (folk) economy. ${ }^{22}$ Another direction of the transformation of the domestic economy, which Weber considered historically more universal, leads to the rise of the "oikos"23 - large domestic farm (manor). In it the needs of the sovereign obligations of subsistence are satisfied by the craftsmen and farmers personally dependent on him, who themselves are landlords of small domestic households. In pre-modern times the political entities (generally empires) were from an economic point of view unions of such oikos. ${ }^{24}$ The most important reason for the collapse of universal empires (the classic examples - ancient Rome and China) was that in them the market economy was a superstructure on the economic base of subsistence (daily

\footnotetext{
20 Cf. Norkus, Max Weber und Rational Choice, 395, 416.

${ }^{21}$ See Karl Marx, Capital: A Critique of Political Economy, 1 (Penguin: New Left Review, 1982 (first published in 1867)), 711-761. More about the K. Marx's economy typology see Robert J. Holton, 'Marxist Theories of Social Change and the Transition from Feudalism to Capitalism', Theory and Society 10, 6 (1981): 833-867; Claudio J. Katz, 'Karl Marx on the Transition from Feudalism to Capitalism', Theory and Society 22, 3 (1993): 363-389.

22 See Weber, General Economic History, 54-69, 207-224.

${ }^{23} \mathrm{M}$. Weber took over this concept from the mentioned "historical school", which at that time dominated in the economics departments of Germany's universities, see Norkus, 'Andropovo klausimu (II)', 9 .

24 See Weber, General Economic History, 105-110, 112-115. In the 20th c. such an example may be the economic organization of the Soviet Union. For example, in his research Z. Norkus, exacerbating the neo-Weberian analysis of K. Jowitt's communist neo-traditionalism and neopatrimonialism, made clearer the typological kinship of the "socialist" economies with the "oikos economy" described by M. Weber. See Norkus, 'Andropovo klausimu (II)', 5-36; Norkus, Kokia demokratija, koks kapitalizmas?, 229-259.
} 
living needs are met with the help of specific economic support, and most of the economic needs of the state by subsistence obligations), the monetary turnover is not so intense that the money collected by taxes would be sufficient to maintain the state apparatus. ${ }^{25}$ The growing stronger centrifugal forces tear up the universal empire from the inside, she becomes a victim of the conquerors and the "patrimonial cycle" described by M. Weber begins anew. ${ }^{26}$

M. Weber portrays Western development, staring from the Middle Ages, as an unbelievable deviation from the just described typical historical development cycle. ${ }^{27} \mathrm{M}$. Weber links the beginning of this deviation with the phenomenon of the "town economy", characteristic of the "continental city of crafts" of the High Middle Ages (11th-14th c.). He contrasts this type of city with the "coastal cities" or poleis (city-states) characteristic of antiquity and the Middle Ages in southern Europe, which were primarily settlements of soldiers and consumers, and not producers. The continental cities of crafts were the nurseries of rational capitalism. Similarly, K. Marx depicted the origins of industrial capitalism in his main work "Capital", deriving it from ordinary commercial production, which is the equivalent of K. Bücher's "town economy". From the view point of K. Marx, industrial capitalism - is the product of the differentiation of small manufacturers due to the ongoing competition. K. Marx calls this differentiation the "original accumulation of capital", which in the 16th and 17th c. the great geographical discoveries and centralized state coercion accelerated even more. From M. Weber's viewpoint, K. Marx does not value sufficiently the authority of the traditionalistic business ethics defended by the Catholic Church, which denounced "greed", the braking effect on this process. Such economic ethics justified certain economic policies, carried out by politically independent medieval towns. Both of these factors hindered and restricted competition. From the comparative analysis of Z. Norkus on the explanations of K. Marx and $\mathrm{M}$. Weber for the emergence of capitalism, it becomes clear by what $\mathrm{M}$. Weber's interpretation of the emergence of modern capitalism is superior

\footnotetext{
25 See Weber, General Economic History, 54-63, 244-247.

26 As we will see later, I. Wallestein describes the collapse of the (universal) empires almost identically.

27 See Weber, General Economic History, 233-252. See also Norkus, Max Weber und Rational Choice, 387-396.
} 
to that of K. Marx. ${ }^{28} \mathrm{~K}$. Marx does not explain from where the motive to reinvest profit arose, which was characteristic for the wealthy artisans and merchants of the Protestant North Western Europe, but not of the Catholic Italy. The latter used their profits to purchase estates, they would leave business and become rentiers who had taken over the lifestyle of the nobles. From M. Weber's point of view, ascetic Protestantism contributed significantly to the emergence of rational capitalism, promoting the reinvestment of profit and presenting such ethics that anticipated the needs of its functioning. ${ }^{29}$ However, this was only possible because these changes determined by religions occurred at the same time as important shifts in the sphere of politics (one of the most important - the creation of centralized states). ${ }^{30} \mathrm{M}$. Weber specifically considered "rational" capitalism as modern, which he demanded to be distinguished from the historically universal "not rational" forms of capitalism. Just as K. Bücher, M. Weber links modern capitalism primarily to the "national economy" step. In the latter case if ever greater and more varied resources are distributed through exchanges of the market, there is more capitalism in the "national economy" or the national economy is thus "more rationally capitalistic". But M. Weber makes an important reservation declaring that "the national economy" becomes "rational capitalistic" only by meeting these necessary conditions: 1) the interlocal market developed in it for goods of mass demand and the mass production of such goods, 2) in it the markets for the means, land and labor force of production are developed; 3) in it are developed the capital market (the most important players in such markets are banks) and the market for goods not yet produced, which are traded when making the so-called term deals on exchanges. ${ }^{31} \mathrm{M}$. Weber sees the origins of rational capitalism as a system of innovative economy in the 16th c. However, the final entrenchment of this system, when daily needs were satisfied in a capitalist way, he identifies with the West, and only from the second-half of the 19th c.. ${ }^{32}$

\footnotetext{
28 See Norkus, Max Weber und Rational Choice, 392-396.

29 See Weber, The Protestant Ethic and the Spirit of Capitalism.

30 See Weber, General Economic History, 248-249. See also Norkus, Max Weber und Rational Choice, 393-401.

31 See Weber, General Economic History, 207-213. See also Norkus, Max Weber und Rational Choice, 348-350.

32 Weber, General Economic History, 208.

66
} 
M. Weber applied his own concept of the economic history of the world in researching the history of the paranasal economy of Western European countries (primarily - of England). On the sidelines of his research remained the economic development of the less developed countries, and therefore his theory lacks the analytical criteria, allowing one to recognize and explain the history of European states that experienced different economic social development.

\section{2 Ideas of the analysis of Marxist and neo-Marxist economic development}

One can correct the discussed "deficiency" of M. Weber by applying the Marxist models analyzing the development of the economy of less developed countries. They allow one to answer the question, what is the relationship between the capitalism of the developed countries analyzed by $\mathrm{M}$. Weber and the feudalism of underdeveloped countries in modern times. We can find one of the most detailed explications of the structure of an undeveloped (corvée farmstead) from the Marxist point of view in the already turned into a classic work of one of the most famous historians of Polish economics Witold Kula (1916-1988) "An Economic Theory of the Feudal System. An Attempt of a Model". ${ }^{33}$ W. Kula's model does not claim to disclose all the patterns of a feudal economy. The objectives of the historian were: 1) using the farming relationships that dominated in the 16th18th-c. in Poland (the era of the dominance of the corvée farmstead economic system) to construct a scheme of the functioning of the feudal economy, 2) with the categories of political economy to explain one of the central problems in Polish historiography - the rise of the Polish-Lithuanian Commonwealth (PLC) and the reasons for the subsequent crisis and decline. To implement these goals W. Kula, despite being a proponent of Marxist access, uses the ideas of the leader of the French "Annales" school of historiography Fernand Braudel. The Polish historian investigates the socio-

\footnotetext{
33 Witold Kula, Teoria ekonomiczna ustroju feudalnego: Próba modelu (Warszava: Państwowe Wydawnictwo Naukowe, 1962). This theoretical work of the feudal economy was conceived as the final, summarizing part of the broad study "Problems and Methods of the Economic History" (Witold Kula, Problemy i metody historii gospodarczej (Warszawa: Państwowe Wydawnictwo Naukowe, 1963)), but was published separately. Further we shall rely on the English version of this work (Witold Kula, An Economic Theory of the Feudal System: Towards A Model of the Polish Economy 1500-1800 (London: New Left Books, 1976)), because it takes into account the comments of critics.
} 
economic development of Poland in the 16th-18th c. by taking complementary and expanding sections, i.e. from the perspective of shortterm and long-term structural change. ${ }^{34} \mathrm{He}$ focuses the main attention on the industrial units: to the farmstead economy, the "economy", and the peasant economy. There is research on their structure, budget and those changes that take place due to population growth or decline, fertility, the change in the prices of agricultural production, natural disasters, ravages of war and other influences. In W. Kula's opinion, research of the "behavior" of the mentioned units from the view point of short-term structural changes could reveal the objective results of farming (did the manufactured products have a greater value than the costs of production) and the motivation and direction of the activity of the researched unit. ${ }^{35}$

W. Kula assigns the following characteristics to the Polish corvée farmstead economy in the 16th-18th c. as a socio-economic unit: 1) the extensity of the economy: the size of the area cultivated determined the size of the harvest, while the area - the quantity of sleds of the peasants working in the field of the landlord, 2) the pursuit of the optimal (for the benefit of the master) relationship between the land of the master and the plots acceptable for the peasants, 3) the consumer use of the master's appropriated surcharge product (its exchange in the market into other consumer products), and 4) meager investments, i.e. the simple reproduction of the farm - the landowner, even if he "invests" the assets in order to increase the added product, that was usually performed by converting village fields into the master's plowed land or increasing the corvée of these very peasants; 36 5) the very large variation in the size of the marketable production of the farmstead manor farm, mainly determined by the yield of the harvest and

\footnotetext{
34 About the scale of the implementation of these goals see Vasilii V. Dorošenko (" "Model ${ }^{\prime \prime}$ agrarnogo stroja Rechi Pospolitoi XVI-XVIII v. (spory polskich istorikov vokrug knigi Vitolda Kula)', in Ezhegodnik po agrarnoi istorii Vostichnoi Evropy 1965 2. (Moskva: Izdatelstvo Moskovskogo instituta, 1970), 114-129); Zygmunt Bauman ('W. Kula, Teoria ekonomiczna feudalizmu', Studia Socjologiczne 3, 10 (1963): 219-228); Jerzy Topolski ('Teoria ekonomiczna ustroju feudalnego. Na marginesie książki Witolda Kuli', Ekonomista 1 (1964): 137-144); Antoni Mą czak ('O przydatności modeli ekonomicznych na przykladzie wiejskiej gospodarki feudalnej', Kwartalnik Historyczny 70, 3 (1963): 675-690); Michael M. Postan ('The Feudal Economy', New Left Review 109 (1978): 72-77).

35 Kula, An Economic Theory of the Feudal System, 28-29.

36 See Kula, An Economic Theory of the Feudal System, 52, 60.

68
} 
only partially - by market demand. ${ }^{37}$ This analysis by W. Kula of the farmstead manor farm revealed the two-sector nature of Poland's feudal (agrarian) economy in the 16th-18th c.: "in kind" (not related to the market) and "trade" (commercialized). In this economy the essential sector for the peasants was subsistence and for the nobility the monetary. The nobleman agreed with what determined an increase in the monetary profit. However, one should not understand this statement as if the holding of the landlord is completely permeated by "the spirit of the market, i.e. capitalistic. In contrast, W. Kula emphasizes the natural character of the landowner's farm, manifested not only in that the labor force and production facilities did not enter the market, but also the fact that the landowners sought to do with their own resources and, if possible, to avoid monetary expenses. ${ }^{38}$ The peasant households were characterized by an even greater subsistence nature. From here arose the completely opposite (as not in capitalism) reaction of the peasants to the market situation changes. This did not have absolutely any affect either on the volume of the peasants' production or the proportions of its branches. The peasant had to sell part of his produce in order to pay feudal rent and acquire the most essential goods. ${ }^{39}$ So W. Kula makes the essential conclusion that the "company" of late feudalism, even though it was to some extent related to the market or (directly or indirectly) feeling its influence, were essentially of a subsistence nature.

Seeking to evaluate quantitatively the changes that occurred in the 16th-18th c. in Poland (the crisis of feudalism and its manifestations in the economy) from the perspective of long-term structural changes, W. Kula comes to the three working hypotheses. The first one states the decline in the productivity of social work in agriculture in 1550-1795 in Poland. As the area under cultivation and the population increased, a decline in the productivity of the farmstead lands and labor productivity (of one serf) was observed. The yields of the peasant farms and the productivity of one worker were

\footnotetext{
37 That means that the owner of the farmstead farm was not able to have an essential influence on either the quantities of sales or purchase prices even though the very farmstead farm as an object of manufacture was oriented to the market. Moreover, as the decline in agricultural production was mostly determined by non-economic factors (year of poor harvest, plague, war), so also did its restoration and rise occurr without the help of the market mechanism. See Kula, An Economic Theory of the Feudal System, 83.

38 See Kula, An Economic Theory of the Feudal System, 53.

39 See Kula, An Economic Theory of the Feudal System, 68.
} 
somewhat higher than in the corvée farmstead farms.40 The second hypothesis states the strong "external" influence of PLC development in the 16th-18th c. (even though the agricultural sector's dependence on the international market situation was little noticed). PLC trade with the countries of Western Europe is discussed. According to W. Kula, the conditions of the terms of trade, determined by the ratio of the prices of export and import goods, at first glance for the PLC in the 16th-18th c. developed in an entirely favorable manner, but namely this factor significantly increased the influence of the internal regularities, which determined the "rot" of the whole feudal system. ${ }^{41}$ The third hypothesis states the more intensified peasant market ties in the late period of the development of the PLC. Constantly stressing that the "commercial sector" in these farms played a secondary role and the serf's aim to have a surplus and to dispose of it at least in the local market encountered the rather successful opposition of the nobility, W. Kula, nevertheless, still believes that over the last 130 years of the existence of the PLC the commercial level of the peasants' farms did not decrease, but on the contrary - grew. 42

W. Kula considers the middle of the 19th century to be the border of the transition from the era of feudalism to capitalism in Poland. ${ }^{43}$ The uneven, but intensifying development of capitalism in this country emerged only in the first half of the 19th c. In Poland until then neither the forces of free labor nor of the land market, which in M. Weber's conception are the essential features of rational capitalism, had been formed. W. Kula links the genesis of capitalism in Poland, in particular, with the emergence of the manufactories in the first half of the 18th century and their subsequent development ${ }^{44}$.

\footnotetext{
40 The claim of W. Kula that this does not mean that the data of the sources about the greater poverty of the peasants in the 16th-18th c. in Poland are not correct, but testify that the efforts of the serfs were inefffective due to the increase in the corvee norms and the decrease in the assigned plots. See Kula, An Economic Theory of the Feudal System, 90-91.

41 See Kula, An Economic Theory of the Feudal System, 132.

${ }^{42} \mathrm{Kula}$, An Economic Theory of the Feudal System, 161-162.

43 See Kula, Ksztattowanie się kapitalizmu w Polsce (Warszawa: Państwowe Wydawnictwo Naukowe, 1955).

44 About the development of manufactories in Poland and Lithuania, see Kula, Szkice o manufakturach w Polsce XVIII wieku, t. 1, częśc 1-2 (Warszawa: Państwowe Wydawnictwo Naukowe, 1956); Kula, Szkice o manufakturach w Polsce XVIII wieku, t. 2, częśc 3 (Warszawa: Państwowe Wydawnictwo Naukowe, 1956). 
W. Kula treats the farms of Poland and Lithuania in the 16th-19th c. (up to 1861) as feudal. The USA sociologist and historian I. Wallerstein presents a different approach in his conception of the neo-Marxist CWS. 45 In it the development of Lithuania's economy in the 16th-19th c. is regarded as peripheral capitalism. Compared to the ideas of the just discussed researchers of the analysis of the economic development, the CWS theory has two interrelated advantages: 1) it seeks to cover the economic organization of not only the developed, but also backward countries of the world, 2) in its analysis of capitalism it avoids methodological nationalism seeking methodological globalism. ${ }^{46}$

Europe during the 'long' 16th c. (1450-1640) is considered to be the starting point of the CWS development in the image presented by I. Wallerstein. ${ }^{47}$ This system became global in the second half of 19th c., and in the second half of the 20th c. included all the regions of the planet into its structures. ${ }^{48}$ Until the 16th c. the social political and economic life was organized in the borders of social mini-systems and world-empires. I. Wallerstein names the local economic communities as mini-systems. They were closed organisms in which one culture, a limited division of labor, and primitive technology dominated. One can find such mini-systems only in

\footnotetext{
45 The most important sources of the CWS theory are the theory of dependence, F. Braudel's theory of history, the capitalism theory of K. Marx and the theories of Marxist imperialism. Due to the dominant meaning of the Marxist sources the CWS is considered to be a neoMarxist theory, see Christopher Chase-Dunn and Peter Grimes, 'World-Systems Analysis', Annual Review of Sociology 21, (1995): 387-417; Daniel Chirot and Thomas D. Hall, 'WorldSystem Theory', Annual Review of Sociology 8 (1982): 81-106; Darius Žiemelis, 'Immanuelio Wallersteino kapitalistinès pasaulio sistemos teorija', Lietuvos istorijos studijos 16 (2005): 65-81. An important source about the dissemination of I. Wallerstein's thinking is his collection of articles, see Immanuel Wallerstein, The Essential Wallerstein (New York: The New York Press, 2000).

46 The CWS theory was developed in opposition to Eurocentrism, believing in the perpetual (linear) progress of European civilization and downplaying other (non-European) cultures, see William G. Martin, 'The World-Systems Perspective in Perspective: Assessing the Attempt to Move beyond Nineteenth-Century Eurocentric Conceptions', Review (Fernand Braudel Center) 17, 2 (1994): 145-185.

47 It should be noted that the CWS originally included only Western, Southern and Central as well as part of Eastern Europe (I. Wallerstein considers its eastern limit at that time to be the PLC border with Russia), as well as Latin America, but the latter's influence on the formation of this social system was secondary, see Wallerstein, The Modern World-System I: Capitalist Agriculture and the Origins of the European World-Economy in the Sixteenth Century (New York: Academic Press, 1974), 67-129.

48 See Wallerstein, 'The Rise and Future Demise of the World Capitalist System: Concepts for Comparative Analysis', Comparative Studies in Society and History 16 (1974): 387-415.
} 
primitive (of hunters, gatherers) societies. The fate of the mini-systems is dual - they either disappeared after being seized by another mini-system, or having expanded (due to conquests) would be transformed into an economic world - an economic community based on an interlocal division of labor (between the center and the periphery), a multi-faceted culture. All that exists as long as the world-empire "does not swallow" up the economic world. This world was a historically unstable structure - it could fall apart or in it one of the constantly warring political formations could become established. In such an instance, the economic world was transformed into a world-empire. ${ }^{49}$ World-empire lived on conquests and looting. According to I. Wallerstein, they were destined to fail, because in them there was no constant accumulation of the capital necessary to upgrade the method of production. With the expansion of territory the apparatus of suppression would inevitably increase, and as the translocal (domestic) exchanges decreased, the economic basis of the empire would erode. ${ }^{50}$

CWS is an economic world, based on capitalist production and the world division of labor between geo-economic zones, politically organized in the form of a system of sovereign, competing with each other for hegemony states. Capitalism, in I. Wallerstein's opinion, cannot exist if there is a single world state - it needs a system of competing sovereign states. The latter is a phenomenon of the modern era. Independent state coexist side by side, their power is similar, blocking the road to prevent one country from becoming sufficiently strong to seize neighboring countries. They control each other, so that any of them would not become too strong.

An essential feature of the concept of CWS is the differentiation into three economic zones: the core, the periphery and the semi-periphery (according to the role in the hierarchical international division of labor). ${ }^{51}$ Countries are classified according to the role that they play in the world division of labor. Intensive capital accumulation, high wages, most

\footnotetext{
49 Such empires were China, Egypt, Rome, see Wallerstein, 'The Rise and Future Demise of the World Capitalist System', 390-391.

50 The reason - the vicious circle between the increase in the taxes needed to maintain the growing apparatus and carry out external expansion, the resistance arising from this increase, the increase in the necessary apparatus to suppress such resistance, the raising of the taxes needed for this increase, the determined decline in business and exchanges caused by the increase in taxes, the increase in taxes qualified by this decline (seeking to maintain at least the current level of treasury income), and so on.

51 See Wallerstein, The Modern World-System I, 100-103.
} 
advanced technological production, lower labor utilization for production are assigned to the core zone. The states of this zone are in particular very strong economically, they produce complex products, requiring at a certain time the most advanced technologies. In these countries, capital is concentrated most intensively (which is continually invested in production and generates high profits), new ideas are developed and adapted. Such states are politically powerful, effectively protect the national interests of the capitalist class. ${ }^{52}$ The specialization of the peripheral area is the extraction of raw materials and the production of agricultural goods. The countries of this zone, are marked most often by weak statehood or colonial, semi-colonial dependence, are technologically backward, almost have no industry, and the layer of hired workers is sparse. They supply raw materials to the core states and use the excess output production of the core. The political government supports the national class of capitalists less, but special attention is given to the strengthening of the coercive apparatus that helps to maintain the export sector. ${ }^{53}$ It is especially important to note that repressive control of the work force is characteristic for the peripheral capitalist countries. Unlike K. Marx and M. Weber, who classified serfdom, debt slavery, etc. as various forms of non-capitalist production relations, I. Wallerstein does not make an essential difference in the situation of legally hired free-lance workers (forced by economic violence, famine to be subordinate to their employers) and of serfs and slaves. In his view, in determining the nature of the production relations between direct producers and the owners of the means of production, important are not the relations inside individual production units, but the purpose of the production. If the production is assigned for sale and export and world market prices dictate the orientation of production, then also the landowner's manor (farmstead), in which serfs cultivate the landowner's field with their implements and the cotton plantation exploiting the work of slaves are capitalist enterprises. When a country is drawn into the system of the international division of labor, then the slaveholder, feudal and other non-capitalist production relations become capitalistic. And that country is also capitalist, as well as others included in the CWS, but its capitalism is special - peripheral. In the first volume of I. Wallerstein's main work, "The

\footnotetext{
52 See Wallerstein, The Modern World-System I, 349.

53 See Wallerstein, The Modern World-System II: Mercantilism and the Consolidation of the European World-Economy 1600-1750 (New York: Academic Press, 1980), 129-130.
} 
Modern World-System", 54 in which the emergence of the CWS in the 16th c. and its early development is discussed, the socio-economic system of Poland and Lithuania in the 16th-18th c. and is treated (together with America) as the periphery of the CWS at that time.

Semi-peripheral zones - is a kind of synthesis of the core and peripheral zones, which is characterized by a medium level of technological advancement, military power and cost of living. The productivity of the applied technology of the states of this zone are behind those of the core, but in the periphery their industrial goods can compete with the core products, as they are significantly cheaper. Thus, the states of the semi-peripheral zone, using the raw materials supplied by the periphery, produce lower quality products or semi-finished goods and agricultural products. Labor is relatively cheap and skilled. These states of this zone have a quite efficient administrative system; it is often authoritarian. The states of this zone are usually weakened former core states, or states seeking the status of core states. The role of semi-peripheral zone countries in the global division of labor is the export of small quantities of material to the core zone countries, and production - to the peripheral. ${ }^{55}$

The three categories of the geo-economic zone countries are necessary for the CWS structure because none of them could exist without the other. This existence of categories is based on the struggle for the realization of markets, sources of raw materials, to colonize areas suitable for monopolistic control. The core zone states, having abundant capital resources, impose not equivalent exchanges on the peripheral countries in order to obtain cheap raw materials. The CWS remains a stable hierarchy of three categories of countries, but in it there is a constant rotation of the countries of the core, peripheral and semi-peripheral zones, a constant struggle for control of resources. A sufficient quantity of capital determines this, but it migrates from one geo-economical zone to another. Among the CWS core zone countries there are competitions for hegemony. From these,

\footnotetext{
54 I. Wallerstein's work "The Modern World-System" is considered to be a story about the history of the development of the CWS, but it is not finished, the four volumes covering the 16th-first half of 20th c. have been published, see Wallerstein, The Modern World-System I; Immanuel Wallerstein, The Modern World-System II; Wallerstein, The Modern World-System III: The Second Great Expansion of the Capitalist World-Economy (New York: Academic Press, 1989); Wallerstein, The Modern World-System IV: Centrist Liberalism Triumphant, 1789-1914 (Berkeley: University of California Press, 2011).
}

55 See Wallerstein, The Modern World-System I, 349. 
for a limited time one economically, politically, militarily dominant state arises. 56 Such a hegemonic state does not destroy the other sovereign states - omnipotence in the CWS does not exist. ${ }^{57}$

As we can see, in the conception of the CWS the economies of the countries are differentiated by the place held in the hierarchy of the international division of labor. CWS theory is at the same time an analysis of the geopolitical and economic interaction and typological analysis of the distinguishing features of CWS countries of different structural positions (core, semi-periphery and periphery). The nature of the economy of a certain country is treated in accordance with its position in the CWS, which the structure of its exports and imports shows.

\section{The social and economic reality of Lithuania in the 16 th-} 19th c. (up to 1861) from the perspective of non-Marxist and (neo) Marxist economic conceptions of the economy

What could (and should) one say about the structure of the economy of Lithuania in the 16th-19th c., looking at its (and also at the same time of the whole region of Central Eastern Europe) socio-economic history from the point of view of non-Marxist and (neo) Marxist conceptions of the economy? One has to begin from the fact that the investigated period of the social and economic history of Lithuania in the 16th-19th c. (up to 1861) coincides chronologically with the "national economy" distinguished in the typologies of the development of the economy by K. Bücher and M. Weber, which are identified with the capitalist nature of the economy. Characteristic (in M. Weber's sense) for him as we have already seen is: 1) the developed interlocal markets demand for goods and the mass production of such goods; 2) developed means of production, land, labor market; 3) developed capital markets. No matter how we would try, we will not find these parameters in the 16th-19th c. (up to 1861) socio-economic reality of Lithuania. As we already know, M. Weber finds them only from the second half of the 19th c. in Western Europe (primarily - in England). However, after

\footnotetext{
56 See Wallerstein, 'The Three Instance of Hegemony in the History of the Capitalist WorldEconomy', in Wallerstein, The Essential Wallerstein (New York: The New York Press, 2000), 253-263.

${ }^{57}$ In CWS history up to now three hegemonic states have existed: the Netherlands (16201672), Great Britain (1815-1873), USA (1945- ?), See Wallerstein, 'The Three Instance of Hegemony in the History of the Capitalist World-Economy', 255.
} 
looking closer at the 16th-19th c. (up to 1861) socio-economic development of Lithuania, we find in it an essential attribute, which allows one to tie the investigated period of Lithuania with the "town economy" type distinguished in the typologies of economic development by K. Bücher and M. Weber, which they equated with the economic life (in the 11th-15th c.) of medieval Western Europe - the dominance of ordinary commercial manufacturing. It should be noted that from the viewpoint of traditional Marxist historiography (W. Kula) the economic situation of the 16th-19th c. of Central Eastern European countries is described as the dominance of ordinary commercial production, which is one of the essential features of feudalism. In the CWS conception the agrarian structure in Central Eastern Europe in the 16th-18th c. was also similar in many ways to the "feudalism" of 11th-15th c. Western Europe from a Marxist viewpoint - having in mind the agrarian structure, rather than the political "superstructure". 58 We cannot unambiguously talk about the basically medieval phenomenon - feudalism in Central Eastern Europe (also in Lithuania) in the 16th-19th c. simply because of the fact that from the 16th c. the intensified relations with Western Europe that were supported by evolving capitalist relations, they had an influence on her socio-economic order at that time. This is revealed by a comparative analysis of the structures and trends of development of the manor in Western Europe in the 11th-15th c. and of the farmstead economy in Central Eastern Europe (especially Poland-Lithuania) in the 16th-18th c. ${ }^{59}$ It allows one to answer the problematic question - can we qualify the farmstead farms that existed in 16th-18th c. Lithuania as "grain factories" or "agricultural production factories", producing for the (especially foreign) market? In the CWS conception in Lithuania the commercial farmstead (corvée) economy that appeared after the Wallach reform, exporting agricultural products to the CWS core countries is considered to be peripheral capitalism. The corvée farmsteads of Lithuania and Poland are classified as the same peripheral capitalist enterprises, which in the 18th-19th c. were the coffee and cotton plantations of slaveholders in Brazil and the

\footnotetext{
58 See Žiemelis, 'Lietuva Vidurio ir Rytų Europoje XVI-XVIII amžiuje: „feodalinè reakcija“ ar periferinis kapitalizmas?', Lietuvos istorijos studijos 18 (2006): 51-68.

59 About the first time in historiography carried out comparative analysis of the 11th-15th c. Western European manor and the 16th-18th c. farmstead farm structures of Central Eastern Europe (especially of the CPL) and trends of development see Žiemelis, 'XVI-XVIII amžiaus Abiejų Tautų Respublikos palivarko ūkis marksistiniu bei neoinstitucionalistiniu požiūriu', Lietuvos istorijos studijos 27 (2011): 11-38. 
Southern states of the U.S. The comparative analysis of the structures and trends of development of 11th-14th c. Western European manor and 16th18th c. Central Eastern European (especially PLC) farmstead structures and trends does not allow one to qualify the 16th-18th c. Polish and Lithuanian manor farms, affected by Western Europe's developing capitalist relations, as typical feudal farms (which the medieval manor farms of Western Europe are considered to be). The Western European manor system as an economic and political unit (mini-state) was based on the implicit exchange agreement of the master and peasant ${ }^{60}$, while the farmstead system of Central and Central Eastern Europe (especially PLC) was based on the absolute dominance of the master in respect to the peasants. ${ }^{61}$ The farmstead was only an economic, but not a political entity (the district was such as an autonomous territorial corporation of the nobility). The manor of 11th-15th c. Western Europe and the farmstead farm of 16th-18th c. Central Eastern Europe developed simple commercial production, but the orientation of their production was different. Without the price scissors between the manor's centers and the commercial ports the manor farm was oriented primarily to satisfying the needs in kind of the master. The purpose of the production of the 16th-18th c. PLC farmstead farm due to the price scissors between the domestic and foreign markets (the influence of the CWS) was the production of commercial products, but the received funds were invested not in maximizing the held resources, but to the expansion of the usage of the social elite. Thus, "in the economic behavior of the farmstead owners we miss the features, which summarize the concept of capital accumulation (the persistent investment of profit, technologically upgrading production"62. All of this hinders one from considering the corvée farmsteads of Lithuania as capitalistic enterprises (in the sense of the CWS).

\footnotetext{
60 See Douglass C. North and Robert Paul Thomas, 'The Rise and Fall of the Manorial System: A Theoretical Model', The Journal of Economic History 31, 4 (1971): 777-803; North and Thomas, 'An Economic Theory of the Growth of the Western World', The Economic History Review 23, 1 (1970): 1-17.

61 An exception was Bohemia, in which there existed relatively strong peasant communities, see Sheilagh C. Ogilvie, 'The Economic World of the Bohemian Serf: Economic Concepts, Preferences, and Constraintson the Estate of Friedland, 1583-1692', The Economic History Review 54, 3 (2001): 430-453; Ogilvie, 'Communities and the "Second Sefdom“ in Early Modern Bohemia', Past EPresent 187 (2005): 69-119; Tracy K. Dennison and Ogilvie, 'Serfdom and Social Capital in Bohemia and Russia', The Economic History Review 60, 3 (2007): 513-544. 62 Norkus, 'Kapitalizmo raidos Lietuvoje bruožai ir etapai (iki 1940 m.) postmarksistiniu požiūriu', 20.
} 
In the CWS conception it was adequately observed that the international trade prices in such key trading ports as Gdansk, Elbing, Riga (e.g., the increased grain prices in the ports determined the greater volumes of their growth) dictated the production orientation of the farms of Poland and Lithuania. However, in the CWS conception the exterior (interstate trade) influence on the economic and social development of the PLC in the 16th-18th c. is exaggerated. ${ }^{63}$ The mentioned research of W. Kula shows that the prices of the farm products of Poland and Lithuania were determined more not by the demand in the international market, but by the size of the joint harvests in these countries (in a good harvest year, they were lower, and in a poor one - higher). ${ }^{64}$ The large dependence of the economy of Poland and Lithuania on natural, political, and other factors was determined by the work force of man and not technologies. In the 16th-18th c. only an insignificant part of the agricultural production of the Polish-Lithuanian state (e.g., in the most intense period of the 16th-middle of 17th c. the grain exports from these countries to the international market comprised about 5 $6 \%$ of total exports) was exported. 65 In the 16th-18th c. in the regions of the PLC distant from the main commercial ports such as Gdansk, Elbing, and Riga an autonomous (related to the internal market), and not expansive (export-oriented) model of the farmstead farm dominated. ${ }^{66}$ As the research of W. Kula shows, only the owners of large latifundia were involved in

\footnotetext{
63 About the problematic place of the CWS conception - the excessively overvalued influence of the exterior (international trade) in the 16th-18th c. on the development of the countries' economy, see e.g., Patrick O'Brien, 'European Economic Development: The Contribution of the Periphery', The Economic History Review 35, 1 (1982): 1-18; Steve J. Stern, 'Feudalism, Capitalism, and the World-System in the Perspective of Latin America and the Caribbean', The American Historical Review 93, 4 (1988): 829-872.

64 See Kula, An Economic Theory of the Feudal System, 82-111.

65 See Jerzy Topolski, 'Eksport płodów rolnych a problem oceny sytuacji gospodarczej strefy bałtyckiej w XVI-XVII wieku', in Jerzy Topolski, Gospodarka polska a europejska w XVI-XVIII wieku (Poznań: Wydow, 1977), 92. See also Antoni Mączak ('Export of Grain and the Problem of Distribution of National Income in the Years 1550-1650', Acta Poloniae Historica 18 (1968): 75-98; 'The Sound Toll Accounts and the Balance of English Sea Trade with the Baltic Zone, 1565-1646', Studia Historiae Oeconomicae 3 (1969): 93-113; 'The Balance of Polish Sea Trade with the Wets, 1565-1646', The Scandinavian Economic History Review 18, 2 (1970): 107-142; 'Agricultural and Livestock Production in Poland: Internal and Foreign Markets', Journal of European Economic History 1, 3 (1972): 671-680); Žiemelis, 'The Structure and Scope of the Foreign Trade of the Polish-Lithuanian Commonwealth in the $16^{\text {th }}$ to $18^{\text {th }}$ Centuries: The Case of the Grand Duchy of Lithuania', Lithuanian History Studies 17 / 2012 (2013): 90-122.

66 See Žiemelis, 'XVI-XVIII amžiaus Abiejų Tautų Respublikos palivarko ūkis marksistiniu bei neoinstitucionalistiniu požiūriu', 11-38. 
international trade, and the owners of medium and small estates sold their commercial production either to the owners of the latifundia or in the internal market.67 The participation of Lithuania in international trade (compared to Poland) was sporadic and more dependent on the year's harvest, wars, epidemics, and so on. ${ }^{68}$ Finally, contrary to what the CWS conception declares, in the middle of the 17th - end of the 18th c. the basis of the income of the PLC manor farm was not based on the realization of agricultural products in the domestic and foreign markets: the main income of Poland's manors consisted of the sale of vodka and beer in the domestic market, ${ }^{69}$ and of Lithuania's - the monetary rents - činšas (feudal land rent) and rents from taverns and mills. ${ }^{70}$

Admitting that the CWS theory values too much the influence of external factors on the social and economic development of Lithuania in the 16th-18th c., nevertheless, on has to emphasize that during the period researched the structure of Lithuania's exports, which from the viewpoint of the CWS shows most completely the nature and location of the national economy in the CWS, most clearly reveals the peripheral capitalistic nature of Lithuania' economy. For example, in the commodity structure of Lithuania's export from the 16th c. until the second half of the 18th c. flax production occupied the central place. From Lithuania hemp and its seeds, skins and its products, malt, potash, timber and grain were also shipped. The last two products in the second half of the 18th c. occupied an essentially important (after linen production) place in the commodity structure of Lithuania's export. The prevailing export goods for a long time were not the product of the farmstead farms - in the16th-first half of 18th c. the central place was occupied by linen production mostly of peasant origin and only in the second half of the 18th c. began the massive exports of grain, which were mainly grow in corvee farmsteads. The fact that in the commodity structure of Lithuania's exports agricultural and forest products dominated, was determined not only by the fact that Lithuania's farmstead farm did not produce products with high added value, but also that it was determined by

\footnotetext{
${ }^{67}$ Kula, An Economic Theory of the Feudal System, 139.

68 See Žiemelis, 'The Structure and Scope of the Foreign Trade of the Polish-Lithuanian Commonwealth in the $16^{\text {th }}$ to $18^{\text {th }}$ Centuries: The Case of the Grand Duchy of Lithuania', 90122.

${ }^{69}$ See Kula, An Economic Theory of the Feudal System, 139-140; Hillel Levine, 'Gentry, Jews, and Serfs: The Rise of Polish Vodka', Review (Fernand Braudel Center) 4, 2 (1980): 223-250.

70 See Mečislovas Jučas, Baudžiavos irimas Lietuvoje (Vilnius: Mintis, 1972), 104-126.
} 
the wants of the Western European market. For example, some types of high quality Lithuanian flax were needed for the production of some fabric fibers of Western European countries, the demand for Lithuanian forest goods was determined by the growing needs of Western shipping industry, the grain supply (in the second half of the 18th c.) increased due to the especially increased demand for them in the West. ${ }^{71}$

After the collapse of the CPL (in which the GDL was one of the two components of the PLC) the greater part of ethnographic Lithuania became part of the Russian Empire, it entered into the European part of its economic system and became subject to the serfdom policies of its state. What impact on the socio-economic development of Lithuania until 1861 (i.e. until the abolition of serfdom) did this have? Did a qualitatively different stage of development of the Lithuanian economy begin? The specific economic situation of the Russian Empire at the end of the 18th c. - the 19th c. provides answers to these questions. Taking into account the high level of the political status of Russia, I. Wallerstein stated that Russia entered the CWS with a semi-peripheral status. ${ }^{72}$ For example, from the viewpoint of Russian analyst B. Kagarlitsky, Russia (apart from the Soviet period, when it tried to destroy the CWS) was always the CWS periphery. ${ }^{73}$ In this problematic retrospective Z. Norkus, taking into account the fact that Russia's government always maintained control of the country's economic ties with CWS, ${ }^{74}$ trying to use them for the purposes of its imperial expansion, according to Russia's economic engagement in the world declares the nature of the entry of

\footnotetext{
${ }^{71}$ For more information about the commodity structure of Lithuania's exports and imports in the 16th-19th c. (until 1861) see Karl von Loewe, 'Commerce and Agriculture in Lithuania, 1400-1600', The Economic History Review 26, 1 (1973): 23-37; Linas Truska ir Rimas Jasas, 'Vneshniaia torgovlia Velikogo Kniazhestva Litovskogo v poslednie gody sushchestvovania (1785-1792)', Lietuvos TSR Mokslu akademijos Darbai, serija A, 1, 32 (1970): 23-53; Leonid Źytkowicz, 'Kilka uwag o handlu zewnętrznym Wielkiego Księstwa Litewskiego w ostatnich latach Rzecypospolitej', Zapiski Historyczne 41, 2 (1976): 87-101; Vytautas Merkys, 'Eksport zerna i lna iz Litvy v 1795-1861 g.', in Ezhegodnik po agrarnoi istorii Vostichnoi Evropy 1963 g. (Vilnius: Mintis, 1964): 436-447; Žiemelis, 'The Structure and Scope of the Foreign Trade of the Polish-Lithuanian Commonwealth in the $16^{\text {th }}$ to $18^{\text {th }}$ Centuries: The Case of the Grand Duchy of Lithuania', 90-122.

72 Wallerstein, The Modern World-System II, 209.

73 See Boris Kagarlitsky, Empire of the Periphery. Russia and the World System (London: Pluto Press, 2008).

74 The most important tools for the subjugation of the periphery to the CWS core in the 19th c. were loans, cheap goods and the military power of the Great Britain's fleet, which would compel the economically backward countries to open their borders to the goods and entrepreneurs of the Western states.
}

80 
Russia's economic world into the CWS, but not the subordinate integration nature of the CWS.75 A result of the partial integration of tsarist Russia into the CWS was inside it at the same time as when the CWS formed a hierarchical inter-regional structure of the division of labor. In it stood out the "core" areas and peripheries producing the higher value-added production (but only for the internal market), the economic specialization of which were not only the manufacture of export production for the international CWS market, but also the provision of raw materials and agricultural products to Russia itself as a CWS semi-peripheral region of industrial centers. Z. Norkus said that the interaction of both processes - the integration of the Russian Empire in the CWS with a semi-peripheral status and the internal differentiation of its economic space determined the specific geography of the differentiation of Russia's economic space. Because of it not only the great imperial metropolitan megacities (Moscow and St. Petersburg), but also the territories which from the viewpoint of political geography were the political periphery (colonies) of the empire developed economically the fastest. In addition to the so-called "new Russian" lands on the Black Sea, to it belonged the provinces of Courland, Liflandia and Estland, the ports (Riga, Liepaja, Tallinn) of which became the empire's "windows to Europe." The greater part of ethnographic Lithuania, according to Z. Norkus, did not join the fastest developing areas of Russia's economic world namely because of the absence of ports. Therefore, the Russian government was not interested in promoting its economic development. The railroad accentuated this direction even more from the second half of the 19th c. Its lines linked the Baltic ports in current Estonia (Narva and Tallinn) and Latvia (Liepaja and Riga) to the inner regions of tsarist Russia, and from then Estonia and Latvia, but not Lithuania finally became major industrial centers of the Russian Empire. ${ }^{76}$ Lithuania which in the 16th-18th c. had been a granary of raw materials for the countries of Western and North Western Europe due to its incorporation into Russia from the end of the 18th c.beginning of the 20th c. became the agrarian periphery of the empire. All of this even more "conserved" the peasant production for family consumption in agriculture, determined the weak development of Lithuania's cities. S. Pamerneckis, one of the few that applied the statistical method for

\footnotetext{
75 Norkus, ‘Kapitalizmo raidos Lietuvoje bruožai ir etapai (iki 1940 m.) postmarksistiniu požiūriu', 21.

76 See Norkus, Kokia demokratija, koks kapitalizmas?, 598-599.
} 
investigating the evolution and dynamics of agrarian relations at the end of the 18th c. - the first half of 19th c. in Lithuania, names Lithuania's economic status in tsarist Russia as follows: "at the end of the 18th c.-first half of the 19th c. simple commodity production dominated and grew stronger in Lithuania [both K. Bücher and M. Weber link it with the "town economy" type - D. Ž.] The reckless increases in the annuity rates, resulting in the stagnation of total agricultural production, which has nothing to do with qualitative shifts, i.e. the beginning of capitalism, made up the basis of the intensity of farmstead production. Its emergence in the structure of agrarian relations is tied to the post-reform period (i.e. after the abolition of serfdom in 1861 - D. Ž.)". ${ }^{77}$ S. Pamerneckis considers Lithuania together with the Belarusian territories as the most "preserved" nook of serfdom relations in the European part of the Russian Empire. Finally, Z. Norkus fills out the typological characteristics of the economic development of the greater part of ethnographic Lithuania in the composition of the Russian Empire in the following way: "When the greater part of ethnographic Lithuania became a part of tsarist Russia at the end of the 18th c., the from the 16th c. occurring country's involvement in the hierarchical international division of labor in the framework of the capitalist world-system (CWS) was deformed, when Lithuania became a colonial double periphery (the periphery of the economic space of Russia as a semi-peripheral CWS country)" ${ }^{78}$

\section{Conclusions}

1. We can find the most influential concepts of non-Marxist economic development in the works of two representatives of the second half of the 19th c.-first half of the 20th c. "historical school" in Germany's national economy K. Bücher and M. Weber. In K. Bücher's non-Marxist evolutionary typology of economic development a distinction is made of "the domestic economy" (i.e. the in kind economy, producing for the use of its members), "the town economy" (that is the local economy of exchanges) and "the national economy" (that is the interlocal exchange economy, in which mass production is focused on the anonymous market). The domestic economy is assigned to antiquity, the town economy - to the Middle Ages, the national economy - to the newest times and identified with capitalism. Although

\footnotetext{
77 Pamerneckis, Agrariniu santykiu raida ir dinamika Lietuvoje, 115.

78 Norkus, 'Kapitalizmo raidos Lietuvoje bruožai ir etapai (iki 1940 m.) postmarksistiniu požiūriu', 35 .

82
} 
M. Weber takes over K. Bücher's isolated steps as "ideal types", he, however, rejects his one-way nature of economic development. In M. Weber's theory of economic development, which is considered to be not only a (critical) addition to K. Bücher's evolutionary typology of economic development, but also an alternative to K. Marx's "dialectical" concept of economic development, not one but two directions of the alternative development of primitive subsistence "domestic economy" are provided. They are: 1) the historically universal "oikos" - the appearance of the large domestic farm (manor); 2) the "town farm", characterized by local markets in which for the exchanges of daily consumption commodities their direct manufacturers meet. From it is formed either an "irrational" form of capitalism or, under certain historical conditions, (ascetic Protestantism and the creation of centralized states) rational capitalism as an economic system of the national economy characteristic only for Western Europe of the newest times.

2. The concept of the European-centric nature of the history of the world economy presented by $\mathrm{M}$. Weber reflects the qualitative changes in the organization of the economic life in the most developed countries of Western Europe (primarily - in England), so it is insufficient for the analysis of the socio-economic reality of less developed countries. Better suited for the analysis of the economic development of less developed countries are the conceptions of the Marxist (W. Kula's feudal economic model) and the neoMarxist (I. Wallerstein's concept of CWS). The model of the feudal economy of the 1960s by Polish economic historian W. Kula reveals the differences and similarities of modern feudalism (in an economic organization) in the underdeveloped countries of Europe with medieval feudalism in Western Europe. In it the farmstead economy of the 16th-18th c., although to some extent related to the domestic and cross-border markets, is essentially of an in kind nature. The 1970s CWS theory of American sociologist and historian I. Wallerstein rejecting European-centric access is at the same time a different structural position (core, semi-peripheral and peripheral) in the analysis of CWS consuming countries' economic and geopolitical interactions and their typological distinguishing features. The nature of the economy of a certain state is treated according to its location in the CWS, which shows the structure of its exports and imports. Farms of core-zone countries produce and export the technologically most advanced at that time products, having the highest added value. The opposite of these paranasal farms at the bottom of the hierarchy of the international division of labor are the farms of 
peripheral capitalism states. In the export structure of the economy of these countries various types of raw materials dominate. The farms of the semiperipheral countries occupy an intermediate position in the international division of labor. In their export structure various types of raw materials and products of lower added value dominate.

3. Looking at the socio-economic development of Lithuania in the 16th-19th c. (up to 1861), we find in it an essential attribute - the dominance of ordinary commercial manufacturing. In K. Bücher's and M. Weber's typology of economic development such economies are attributed to the "town farm" type, which they equated with the medieval economic life of Western Europe (in 11th-15th c.). From the viewpoint of representatives of traditional Marxist historiography (W. Kula) the dominance of ordinary commercial manufacturing is considered one of the essential features of the feudal economy of Central Eastern Europe in 16th-19th c. In the CWS conception many features of the agrarian system of Central Eastern European in the 16th-18th c. remind one of the 11th-15th c. "feudalism" of Western Europe from a Marxist perspective (having in mind the agrarian system, rather than the political "superstructure"), however, due to the changed international context (i.e. the CWS, which did not exist in the 11th15th c. in Western Europe) the socio-economic system of this region is considered to be a zone of peripheral capitalism.

4. In studies of Lithuania's economic history one perceives in the 16th-18th c. the too meager involvement of Lithuania's economy in the inter state market (in the CWS sense), the uncharacteristic features of capital accumulation by the owners of commercial corvée farmsteads show the feudal nature of its economy. However, the observed stable structure of the export of the residual farmstead production still allows one to talk about the existence of elements of peripheral capitalism. After Lithuania was incorporated into the Russian Empire in 1795 - a semi-peripheral CWS space carrying out the policies of a serfdom economy - its economy due to the lack of a port was not oriented to industry, but the extraction of raw materials for the imperial centers and the Western market, due to which the agrarian nature of its economy became even stronger. Its economic situation until 1861 was identified as a "periphery in a semi-periphery." 


\section{References:}

Antanaitis, Kastytis. Sovietiné Lietuvos, Latvijos ir Estijos nomenklatūra (19531990 m.: Désningumai ir ypatumai, Daktaro disertacija (Vytauto Didžiojo Universitetas, 2001).

Babinskas, Nerijus. Economic Challenges of the Early Modern Ages and Different Responses of European Margins: Comparative Considertions on the Basis of Historiography (The Cases of PolishLithuanian Commonwealth and Moldavian Principality), Revista Română de Studii Baltice și Nordice / The Romanian Journal for Baltic and Nordic Studies 4, 2 (2012): 51-62.

Bauman, Zygmunt. 'W. Kula, Teoria ekonomiczna feudalizmu', Studia Socjologiczne 3, 10 (1963): 219-228.

Bumblauskas, Alfredas. 'Lietuvos istorijos periodizacijos modeliai socialinès istorijos požiūriu', Lietuvos istorijos studijos 17 (2006): 9-26.

Bumblauskas, Alfredas. Senosios Lietuvos istorija 1009-1795 (Vilnius: R. Paknio leidykla, 2005).

Bücher, Karl. Vozniknovenie narodnogo hoziaistva: publichnyje lekcii i ocherki / perevod pod redakciei i s predisloviem I. M. Kulishera. Vypusk pervyi (Sankt Peterburg, 1907).

Bücher, Karl. Die Entstehung der Volkswirtschaft. Sechs Vorträge (Tübingen: Verlag der H. Laupp'schen Buchhandlung, 1893).

Chase-Dunn, Christopher and Grimes, Peter. 'World-Systems Analysis', Annual Review of Sociology 21, (1995): 387-417.

Chirot, Daniel and Hall, Thomas D. 'World-System Theory', Annual Review of Sociology 8 (1982): 81-106.

Dennison, Tracy K. and Ogilvie, Sheilagh C. 'Serfdom and Social Capital in Bohemia and Russia', The Economic History Review 60, 3 (2007): 513544.

Dorošenko, Vasilii V. '"Model" agrarnogo stroja Rechi Pospolitoi XVIXVIII v. (spory polskich istorikov vokrug knigi Vitolda Kula)', in Ezhegodnik po agrarnoi istorii Vostichnoi Evropy 1965 2. (Moskva: Izdatelstvo Moskovskogo instituta, 1970): 114-129.

Ghosh, Peter. 'From the 'Spirit of Capital' to the "Spirit" of Capitalism: The Transition in German Economic thought between Lujo Brentano and Max Weber', History of European Ideas 35, 1 (2009): 62-92. 
Hall, John R. 'Where History and Sociology Meet: Forms of Discourse and Sociohistorical Inquiry', Sociological Theory, 10, 2 (1992): 164-193.

Holton, Robert J. 'Marxist Theories of Social Change and the Transition from Feudalism to Capitalism', Theory and Society 10, 6 (1981): 833-867.

Jučas, Mečislovas. Baudžiavos irimas Lietuvoje (Vilnius: Mintis, 1972).

Kagarlitsky, Boris. Empire of the Periphery. Russia and the World System (London: Pluto Press, 2008).

Katz, Claudio J. 'Karl Marx on the Transition from Feudalism to Capitalizm', Theory and Society 22, 3 (1993): 363-389.

Kula, Witold. An Economic Theory of the Feudal System: Towards A Model of the Polish Economy 1500-1800 (London: New Left Books, 1976).

Kula, Witold. Problemy i metody historii gospodarczej (Warszawa: Państwowe Wydawnictwo Naukowe, 1963).

Kula, Witold. Teoria ekonomiczna ustroju feudalnego: Próba modelu (Warszava: Państwowe Wydawnictwo Naukowe, 1962).

Kula, Witold. Szkice o manufakturach w Polsce XVIII wieku, t. 1, częśc 1-2 (Warszawa: Państwowe Wydawnictwo Naukowe, 1956).

Kula, Witold. Szkice o manufakturach w Polsce XVIII wieku, t. 2, częśc 3 (Warszawa: Państwowe Wydawnictwo Naukowe, 1956).

Kula, Witold. Kształtowanie się kapitalizmu w Polsce (Warszawa: Państwowe Wydawnictwo Naukowe, 1955).

Levine, Hillel. 'Gentry, Jews, and Serfs: The Rise of Polish Vodka', Review (Fernand Braudel Center) 4, 2 (1980): 223-250.

Martin, William G. 'The World-Systems Perspective in Perspective: Assessing the Attempt to Move beyond Nineteenth-Century Eurocentric Conceptions', Review (Fernand Braudel Center) 17, 2 (1994): 145-185.

Mardellat, Patrick. 'Max Weber's Critical Response to Theoretical Economics', The European Journal of the History of Economic Thought 16, 4 (2009): 599-624.

Marx, Karl. Capital: A Critique of Political Economy, 1 (Penguin: New Left Review, 1982 (first published in 1867)).

Mą czak, Antoni. 'Agricultural and Livestock Production in Poland: Internal and Foreign Markets', Journal of European Economic History 1, 3 (1972): 671-680.

Mą czak, Antoni. 'The Balance of Polish Sea Trade with the Wets, 1565-1646', The Scandinavian Economic History Review 18, 2 (1970): 107-142. 
Mą czak, Antoni. 'The Sound Toll Accounts and the Balance of English Sea Trade with the Baltic Zone, 1565-1646', Studia Historiae Oeconomicae 3 (1969): 93-113.

Mączak, Antoni. 'Export of Grain and the Problem of Distribution of National Income in the Years 1550-1650', Acta Poloniae Historica 18 (1968): 75-98.

Mączak, Antoni. ‘O przydatności modeli ekonomicznych na przykladzie wiejskiej gospodarki feudalnej', Kwartalnik Historyczny 70, 3 (1963): 675-690.

Merkys, Vytautas. 'Eksport zerna i lna iz Litvy v 1795-1861 g.', in Ezhegodnik po agrarnoi istorii Vostichnoi Evropy 1963 g. (Vilnius: Mintis, 1964): 436-447.

Nau, Heino Heinrich. 'Gustav Schmoller's Historico-Ethical Political Economy: Ethics, Politics and Economics in the Younger German Historical School, 1860-1917', The European Journal of the History of Economic Thought 7, 4 (2000): 507-531.

Norkus, Zenonas. 'Agrarinių reformu Pirmojoje ir Antrojoje Lietuvos respublikose lyginamoji istorinè sociologinè analizè', Sociologija. Mintis ir veiksmas 1 (30), (2012): 5-52.

Norkus, Zenonas. 'Kapitalizmo raidos Lietuvoje bruožai ir etapai (iki 1940 m.) postmarksistiniu požiūriu', Lietuvos istorijos studijos 29 (2012): 9-36.

Norkus, Zenonas. 'Imperium litewskie w międzyjednostkowych społecznościach i systemach politycznych: studium przypadku', Politeja 2 (2011): 129-154.

Norkus, Zenonas. Nepasiskelbusioji imperija: Lietuvos Didžioji Kunigaikštija lyginamosios istorines imperiju sociologijos požiūriu (Vilnius: Aidai, 2009).

Norkus, Zenonas. Kokia demokratija, koks kapitalizmas? Pokomunistine transformacija Lietuvoje lyginamosios istorines sociologijos požiūriu (Vilnius: VU, 2008).

Norkus, Zenonas. 'Andropovo klausimu (II). Kaip Maxas Weberis atsakytu ì Jurijaus Andropovo klausimą', Sociologija. Mintis ir veiksmas 1 (21) (2008): 5-36.

Norkus, Zenonas. 'The Grand Duchy of Lithuania in the Retrospective of Comparative Historical Sociology of Empires', World Political Science Review 3, 4 (2007): 1-41. 
Norkus, Zenonas. Max Weber und Rational Choice (Marburg: Metropolis Verlag, 2001).

North, Douglass C. and Thomas, Robert Paul. 'The Rise and Fall of the Manorial System: A Theoretical Model', The Journal of Economic History 31, 4 (1971): 777-803.

North, Douglass C. and Thomas, Robert Paul. 'An Economic Theory of the Growth of the Western World', The Economic History Review 23, 1 (1970): 1-17.

O'Brien, Patrick. 'European Economic Development: The Contribution of the Periphery', The Economic History Review 35, 1 (1982): 1-18.

Ogilvie, Sheilagh C. 'Communities and the "Second Sefdom" in Early Modern Bohemia', Past E Present 187 (2005): 69-119.

Ogilvie, Sheilagh C. 'The Economic World of the Bohemian Serf: Economic Concepts, Preferences, and Constraintson the Estate of Friedland, 1583-1692', The Economic History Review 54, 3 (2001): 430-453.

Pamerneckis, Stanislovas. Agrariniu santykiu raida ir dinamika Lietuvoje: XVIII a. pabaiga -XIX a. pirmoji pusé (Statistiné analizè) (Vilnius: VU, 2004).

Pivoras, Saulius. Lietuviu ir latviu pilietinès savimones raida: XVIII a. pabaigaXIX a. pirmoji pusè (lyginamasis aspektas) (Vilnius: VDU, 2000).

Postan, Michael M. 'The Feudal Economy', New Left Review 109 (1978): $72-$ 77 .

Stern, Steve J. 'Feudalism, Capitalism, and the World-System in the Perspective of Latin America and the Caribbean', The American Historical Review 93, 4 (1988): 829-872.

Topolski, Jerzy. 'Eksport płodów rolnych a problem oceny sytuacji gospodarczej strefy bałtyckiej w XVI-XVII wieku', in Topolski, Jerzy. Gospodarka polska a europejska w XVI-XVIII wieku (Poznań: Wydow, 1977): 85-98.

Topolski, Jerzy. 'Teoria ekonomiczna ustroju feudalnego. Na marginesie książki Witolda Kuli', Ekonomista 1 (1964): 137-144.

Truska, Linas ir Jasas, Rimas. ‘Vneshniaia torgovlia Velikogo Kniazhestva Litovskogo v poslednie gody sushchestvovania (1785-1792)', Lietuvos TSR Mokslu akademijos Darbai, serija A, 1, 32 (1970): 23-53.

Tyla, Antanas Lietuvos Didžiosios Kunigaikštystès iždas: XVI amžiaus antroji pusé - XVII amžiaus vidurys (Vilnius: Nacionalinis muziejus Lietuvos Didžiosios Kunigaikštystės valdovų rūmai, 2012). 
Vaskela, Gediminas. Lietuva 1939-1940 metais: Kursas ị valstybés reguliuojama ekonomika (Vilnius: LII, 2002).

Vaskela, Gediminas. Žemés reforma Lietuvoje 1919-1940 m.: Analizuojant Rytu ir Vidurio Europos agrarinès raidos XX a. III-IV dešimtmečiais tendencijas (Vilnius: LII, 1998).

Vaskela, Gediminas. 'The Course towards State-Regulated Economy in Lithuania in 1939-1940', Lithuanian Historical Studies 2 (1997): 151174.

Vaskela, Gediminas. 'The Land Reform of 1919-1940: Lithuania and the Countries of Eastern and Central Europe', Lithuanian Historical Studies 1 (1996): 116-132.

Vaskela, Gediminas. Lietuvos kaimo gyventojai 1920-1940 m. (socialinis ir ekonominis aspektas) (Vilnius: Academia, 1992).

von Loewe, Karl. 'Commerce and Agriculture in Lithuania, 1400-1600', The Economic History Review 26, 1 (1973): 23-37.

Wallerstein, Immanuel. The Modern World-System IV: Centrist Liberalism Triumphant, 1789-1914 (Berkeley: University of California Press, 2011).

Wallerstein, Immanuel. The Essential Wallerstein (New York: The New York Press, 2000).

Wallerstein, Immanuel 'The Three Instance of Hegemony in the History of the Capitalist World-Economy', in Wallerstein, Immanuel. The Essential Wallerstein (New York: The New York Press, 2000): 253-263.

Wallerstein, Immanuel. The Modern World-System III: The Second Great Expansion of the Capitalist World-Economy (New York: Academic Press, 1989).

Wallerstein, Immanuel. The Modern World-System II: Mercantilism and the Consolidation of the European World-Economy 1600-1750 (New York: Academic Press, 1980).

Wallerstein, Immanuel. The Modern World-System I: Capitalist Agriculture and the Origins of the European World-Economy in the Sixteenth Century (New York: Academic Press, 1974).

Wallerstein, Immanuel. 'The Rise and Future Demise of the World Capitalist System: Concepts for Comparative Analysis', Comparative Studies in Society and History 16 (1974): 387-415.

Weber, Max. General Economic History (New York: Collier Books, 1961). 
Weber, Max. The Protestant Ethic and the Spirit of Capitalism (New York: Scribner, 1958).

Weber, Max. Wirtshaftsgeschichte: Abriss der universalen Sozial- und WirtshaftsGeschichte (München: Duncker und Humblot, 1923).

Źytkowicz, Leonid. 'Kilka uwag o handlu zewnętrznym Wielkiego Księstwa Litewskiego w ostatnich latach Rzecypospolitej', Zapiski Historyczne 41, 2 (1976): 87-101.

Žiemelis, Darius 'The Structure and Scope of the Foreign Trade of the PolishLithuanian Commonwealth in the 16th to 18th Centuries: The Case of the Grand Duchy of Lithuania', Lithuanian History Studies 17 / 2012 (2013): 90-122.

Žiemelis, Darius. 'XVI-XVIII amžiaus Abiejų Tautų Respublikos palivarko ūkis marksistiniu bei neoinstitucionalistiniu požiūriu', Lietuvos istorijos studijos 27 (2011): 11-38.

Žiemelis, Darius. 'Lietuva Vidurio ir Rytų Europoje XVI-XVIII amžiuje: „feodalinè reakcija“ ar periferinis kapitalizmas?', Lietuvos istorijos studijos 18 (2006): 51-68.

Žiemelis, Darius. 'Immanuelio Wallersteino kapitalistinès pasaulio sistemos teorija', Lietuvos istorijos studijos 16 (2005): 65-81. 